\title{
Perubahan Siklus Menstruasi pada Akseptor KB Suntik Depo Medroksiprogesteron Asetat (DM PA) dan Implan di Wilayah Kerja Puskesmas Karanan Kabupaten Trenggalek
}

\author{
Debbie Cahya Wenang ${ }^{1}$, Ayu Cahyani Noviana ${ }^{2 *}$ \\ Fakultas Kedokteran Universitas Wijaya Kusuma Surabaya ${ }^{1}$ \\ Bagian Ilmu Kesehatan M asyarakat Fakultas Kedokteran \\ Universitas Wijaya Kusuma Surabaya ${ }^{2}$ \\ e-mail : drayusubagyo@gmail.com
}

\begin{abstract}
ABSTRAK
Efek samping kontrasepsi DMPA dan implan yang paling utama adalah gangguan menstruasi berupa amenore, spotting, perubahan dalam siklus, frekuensi, lama menstruasi dan jumlah darah yang hilang. Hasil survei pendahuluan dari 5 akseptor implan semuanya mengatakan bahwa jumlah menstruasi yang dikeluarkan menjadi lebih lama dan dari 10 akseptor suntik DMPA 8 orang diantaranya mengalami amenore dan 2 orang mengalami spotting. Tujuan penelitian ini adalah untuk mengetahui perbedaan perubahan siklus menstruasi pada Akseptor KB suntik Depo Medroksiprogeteron Asetat (DM PA) dengan akseptor implan di wilayah kerja Puskesmas Karangan Kecamatan Karangan Kabupaten Trenggalek. Penelitian cross sectional ini menggunakan populasi akseptor berjumlah 2.199 orang dengan sampel sejumlah 90 orang. 45 orang akseptor KB suntik DM PA dan 45 orang akseptor KB implan. Variabel terdiri dari akseptor KB suntik DMPA, akseptor KB implan, sebagai variabel bebas dan perubahan siklus menstruasi sebagai variabel terikat. Hasil penelitian menunjukkan bahwa ada perbedaan perubahan siklus menstruasi pada Akseptor KB suntik Depo Medroksiprogeteron Asetat (DM PA) dengan akseptor implan di wilayah kerja Puskesmas Karangan Kecamatan Karangan Kabupaten Trenggalek tahun $2016(\alpha<0,05)$. Untuk menurunkan adanya perubahan siklus menstruasi akibat pengaruh kontrasepsi hormonal disarankan kepada ibu-ibu pasangan usia subur untuk memilih kontrasepsi yang aman dan tidak mempengaruhi terhadap perubahan siklus menstruasi.
\end{abstract}

Kata kunci: akseptor KB suntik DM PA, akseptor KB implan, perubahan siklus menstruasi

\section{Menstruation Cycle Changes of Implant and Medroksiprogesteron Asetat Injection Acceptor at Puskesmas Karangan Kabupaten Trenggalek}

\begin{abstract}
The side effect of Hormonal contraception especially DM PA injection and implant is the changes of menstrual cycle. The changes include amenorrhea, spotting, duration of menstruation, amount of the blood loss etc. 8 of 10 DM PA acceptor has amenorrhea and all of implant acceptor has prolonged period. This research aimed to study the differences changes in menstrual cycle between DMPA Injection and implant acceptor at Puskesmas Karangan, Kecamatan Karangan, Kabupaten Trenggalek. Using cross sectional design and 90 respondents, 45 from DM PA acceptor and 45 from implant acceptor.

The result showed that there was differences in menstrual cycle between DM PA injection acceptor with implant acceptor with $p=0,006, \mathrm{Cl} 95 \%$, contingency coeffisient 0,378 . The changes of menstrual cycle lighter for implant acceptor because of differences kind of ingredient.
\end{abstract}

Keywords: DM PA injection acceptor, implant acceptor, menstrual cycle changes 


\section{PENDAHULUAN}

Gerakan KB nasional adalah salah satu bentuk dari kontrasepsi yang bertujuan untuk pengaturan kelahiran dengan jalan mencegah kehamilan. Upaya ini dapat bersifat sementara maupun bersifat permanen dan upaya ini dapat dilakukan menggunakan cara, alat atau obatobatan(1). Saat ini tersedia banyak metode atau alat kontrasepsi meliputi: IUD, suntik, pil, implant, kontap, kondom(2). Salah satu kontrasepsi yang populer di Indonesia adalah kontrasepsi suntik. Kontrasepsi suntik yang digunakan adalah Noretisteron Enentat (NETEN), Depo Medroksi Progesteron Acetat (DMPA) dan Cyclofem. Jenis kontrasepsi yang banyak digunakan adalah kontrasepsi hormonal yang tersedia dalam bentuk oral, suntik dan implan. Metode kontrasepsi hormonal dianggap salah satu metode dengan tingkat efektifitas yang tinggi, tetapi disisi lain kontrasepsi hormonal terutama yang mengandung progestin dapat mengubah menstruasi. Perubahan ini tidak dapat diduga, bervariasi antara masing-masing wanita sampai beberapa tingkat terhadap metode kontrasepsi. Pada sebagian besar pemakai, terjadi peningkatan insiden bercak darah yang tidak teratur dan sedikit atau perdarahan diluar siklus, siklus yang berkepanjangan, dan oligomenore atau bahkan amenore(1). Jenis kontrasepsi hormonal yang hanya mengandung progestin terdiri dari Mini Pil, KB Suntik DMPA dan implan. Puji Lestari menyatakan bahwa terdapat hubungan antara lama pemakaian DMPA dengan siklus menstruasi, lama menstruasi dan kejadian spotting. Semakin lama penggunaan maka jumlah darah menstruasi yang keluar juga semakin sedikit dan bahkan sampai terjadi amenore(3). Implan termasuk kontrasepsi jangka panjang, sehingga dimungkinkan akan memberikan pengaruh yang berbeda terhadap gangguan menstruasi dibandingkan KB Pil dan Suntik sedangkan keuntungan $\mathrm{Pil}$ yaitu tetap membuat menstruasi teratur(4). Kontrasepsi suntik memiliki kelebihan dan kekurangan. Kekurangan dari kontrasepsi suntik adalah terganggunya pola menstruasi diantaranya adalah amenorrhea, menoragia dan muncul bercak (spotting), terlambatnya kembali kesuburan setelah penghentian pemakaian, peningkatan berat badan(5). Kontrasepsi Implan hampir $100 \%$ efektif mencegah kehamilan. Implan mempunyai keuntungan memiliki efektivitas tinggi karena tidak memiliki angka kegagalan pada pengguna, tidak perlu mengingat minum pil atau memasang diafragma. Permasalahan yang terjadi masih rendah akseptor yang menggunakan KB implant. Hal ini dikarenakan KB implan menyebabkan ketidakteraturan siklus menstruasi(6). Menurut Saifuddin yang menyatakan bahwa jenis KB suntikan banyak dipilih akseptor karena kerjanya yang efektif dan pemakaiannya yang praktis (5). Suntik DMPA aman, dapat dipakai oleh semua perempuan usia reproduksi, cocok untuk masa laktasi karena tidak mengganggu produksi ASI sedangkan KB implanmemiliki kekurangan berupa nyeri kepala, peningkatan atau penurunan berat badan, mual, pening/ pusing, membutuhkan tindakan bedah minor untuk insersi dan pencabutan, tidak melindungi dari infeksi menular seksual, perubahan perasaan (mood) atau kegelisahan (nervousness), efektifitas menurun bila menggunakan obat tuberkulosis (rifampisin) atau obat epilepsi (fenotin dan barbiburat). Keuntungan suntik DMPA adalah pemakaiannya yang sederhana, menyenangkan, efektifitasnya tinggi. Efek samping kontrasepsi DMPA dan implanyang paling utama adalah gangguan menstruasi berupa amenore, spotting, perubahan dalam siklus, frekuensi, lama menstruasi dan jumlah darah yang hilang(1). Kedua jenis kontrasepsi tersebut kandungan hormonnya sama yaitu progesterone namun pengaruh terhadap gangguan menstruasi ada perbedaan, hal ini sesuai dengan teori yang dikemukakan Ekawati yang menyatakan bahwa kontrasepsi implan mempunyai keluhan gangguan menstruasi yang lebih sedikit dibandingkan dengan kontrasepsi suntik DMPA(7). Berdasarkan data Dinas Kesehatan Jawa Timur tahun 2013 Jumlah pasangan usia subur di Jawa Timur pada tahun 2012 sebanyak 6.357 .836 orang, yang menjadi peserta KB baru sebanyak 832.032orang (13,09\%), dan jumlah KB aktif yang telah dibina sebanyak 4.964 .834 orang $(78,09 \%)$. Dari peserta KB baru, jenis kontrasepsi yang digunakanadalah suntik $63,90 \%$, pil $17,12 \%$, implant 10,21\%, kondom 3,39\%, IUD3,09\%, dan MOP / MOW 2,30\%. Pada peserta KB aktif, jenis kontrasepsi yang digunakan adalah suntik $54,84 \%$, pil $17,43 \%$, implant 9,55\%, IUD9,48\%, MOP / MOW 7,28\%, kondom 1,42 (Profil Kesehatan Jawa Timur, 2008). Jumlah pasangan usia subur di Jawa Timur pada tahun 2008 
sebanyak 247.132 orang, sebanyak 36.251 orang menjadi peserta KB baru, dansebanyak 196.482 orang peserta KB lama. Dari peserta KB baru, jeniskontrasepsi yang digunakan adalah suntik $65,49 \%$, pil $20,90 \%$, IUD 5,94\%, kondom $5,46 \%$, implant 5,07\%, dan M OP / MOW 5,63\%. Pada peserta KB aktif, jenis kontrasepsi yang digunakan adalah suntik $43,98 \%$, pil $12,13 \%$, IUD $6,17 \%$, implant $5,45 \%$, kondom $4,80 \%$, MOP / MOW 6,97\% (Profil Kesehatan Jawa Timur, 2008). Hasil survei wanita KB aktif Badan Keluarga Berencana Dan Pemberdaya Wanita (BKBPP) di Kabupatan Trenggalek tahun 2014 menujukkan kontrasepsi hormonal yang dipakai responden Pasangan Usia Subur (PUS) terbanyak adalah suntik sebesar 89.335 jiwa dan berikutnya adalah pil 29.601 jiwa, implan14.235 jiwa. Jumlah akseptor hormonal terbanyak di Kabupaten Trenggalek adalah Kecamatan Karangan sebanyak 11.029 jiwa. Hasil survei Petugas Penyuluh Lapangan Keluarga Berencana (PPLKB) wanita KB aktif Puskesmas Karangan pada tahun 2015 menunjukan bahwa akseptor implanadalah 651 jiwa dan akseptor suntik DMPA 1.548 jiwa. Berdasarkan hasil survey pendahuluan dari 5 akseptor implansemuanya mengatakan bahwa jumlah menstruasi yang dikeluarkan menjadi lebih lama dan dari 10 akseptor suntik DMPA 8 orang diantaranya mengalami amenore dan 2 orang mengalami spotting. Berdasarkan data di atas penulis tertarik mengambil penelitian dengan judul perbedaan perubahan siklus menstruasi pada Akseptor KB suntik Depo Medroksiprogeteron Asetat (DMPA) dengan akseptor implan di wilayah kerja Puskesmas Karangan Kecamatan Karangan Kabupaten Trenggalek.

\section{METODE PENEUTIAN}

Dalam penelitian ini populasinya adalah semua ibu akseptor Keluarga Berencana (KB) suntik DPMA dan KB implan di wilayah kerja puskesmas Karangan Kabupaten Trenggalek tahun 2015. Populasi akseptor KB implan dan akseptor KB suntik DMPA sebanyak 2.199 jiwa. Besar sampel yang akan diteliti dengan menggunakan rumus dari Lemeshow yaitu 90 yang terdiri dari 45 orang akseptor KB suntik DMPA dan 45 orang akseptor KB implan. Penelitian ini menggunakan desain penelitian deskriptif analitik yaitu penelitian yang diarahkan untuk mendeskripsikan atau menguraikan suatu keadaan di dalam suatu komunitas atau masyarakat dalam suatu hubungan sebab akibat(8). Dalam penelitian ini sampel diambil dengan cara systematic random sampling yaitu merupakan modifikasi dari sampel random sampling. Teknik pengumpulan data pada penelitian ini adalah menggunakan koesioner. Kuesioner dikumpulkan setelah responden menjawab semua pertanyaan yang telah dijawab sesuai dengan keadaannya dengan memberi tanda silang ( $X$ ) pada jawaban yang telah disediakan. Analisis data menggunakan analsis univariat dan bivariat (Chi Square).

\section{HASIL PENELITIAN}

Berdasarkan hasil survei diketahui bahwa hampir seluruh responden yaitu 35 atau sebesar $77,78 \%$ akseptor yang menggunakan akseptor KB suntik DM PA mengalami gangguan menstruasi, dengan gangguan terbanyak adalah amenore sebesar $43 \%$.

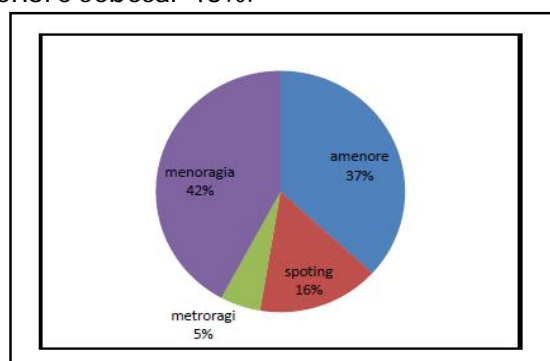

Gambar 1. Karakteristik Jenis Gangguan Menstruasi pada Akseptor Suntik DM PA

Sedangkan pada akseptor implan diketahui bahwa hampir seluruh responden yaitu 26 atau sebesar 57,78\% akseptor yang menggunakan KB implant tidak mengalami perubahan siklus menstruasi. Gangguan siklus yang dialami dapat dilihat pada gambar 2, dimana gangguan siklus terbanyak adalah menoragi sebesar $42 \%$

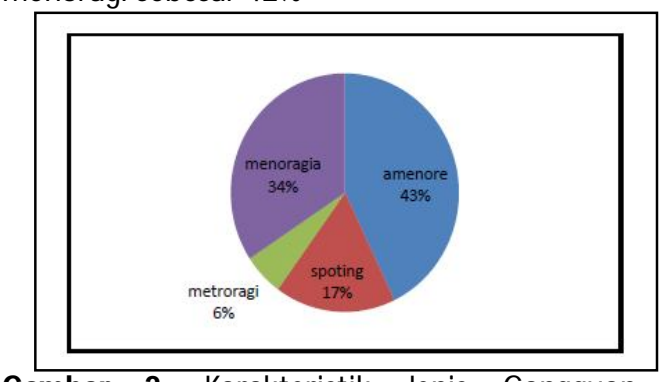

Gambar 2. Karakteristik Jenis Gangguan Menstruasi pada Akseptor implan 
ISSN 1978-2071 (Print); ISSN 2580-5967 (Online)

Jurnal IImiah Kedokteran Wijaya Kusuma 6 (1) : 8-13

Tabel 1. Gangguan siklus menstruasi pada akseptor KB suntik DM PA dan implant

\begin{tabular}{|c|c|c|c|c|c|c|c|}
\hline \multirow[t]{3}{*}{ Akseptor KB } & \multicolumn{6}{|c|}{ Perubahan siklus menstruasi } & \multirow[t]{3}{*}{$p$} \\
\hline & \multicolumn{2}{|c|}{ Mengalami } & \multicolumn{2}{|c|}{ Tidak mengalami } & \multicolumn{2}{|c|}{ Total } & \\
\hline & $f$ & $\%$ & $f$ & $\%$ & $f$ & $\%$ & \\
\hline $\begin{array}{l}\text { KB suntik } \\
\text { DMPA }\end{array}$ & 35 & 77,78 & 10 & 22,22 & 45 & 100 & 0.006 \\
\hline KB implan & 19 & 42,22 & 26 & 57,78 & 45 & 100 & \\
\hline Total & 54 & 60 & 36 & 40 & 90 & 100 & \\
\hline
\end{tabular}

Pada tabel 1. menunjukkan bahwa akseptor yang mengalami perubahan siklus menstruasi paling banyak pada akseptor KB suntik DMPA $(77,78 \%)$ dan yang tidak mengalami perubahan siklus menstruasi pada KB implan (57,78\%). Hasil uji statistik diperoleh nilai $p=0,006$ yang lebih kecil dari $\alpha=0,05$; artinya HO ditolak dan H1 diterima atau ada perbedaan pengaruh perubahan siklus menstruasi antara akseptor yang menggunakan alat kontrasepsi kontrasepsi suntik Depo Medroksi Progesterone Asetat (DM PA) dengan Implan di Wilayah Kerja Puskesmas Karangan Kecamatan Karangan Kabupaten Trenggalek Tahun 2016.

\section{PEMBAHASAN}

Hasil penelitian ini menunjukan bahwa KB suntik banyak diminati karena dianggap harganya yang relatif lebih murah dan pemakaiannya yang sederhana. Masyarakat Wilayah Kerja Puskesmas Karangan Kecamatan Karangan Kabupaten Trenggalek sebagian besar tinggal di daerah terpencil yang kehidupannya masih sederhana hal ini mempengaruhi dalam pemilihan alat kontrasepsi yang harganya terjangkau yaitu KB suntik. KB implan kurang diminati karena harganya dianggap lebih mahal dari KB suntik selain itu masih banyak wanita yang merasa takut meggunakan KB implan karena pemasangannya harus melalui operasi kecil (bedah minor) dan dianggap berbahaya. Penelitian ini sejalan dengan penelitian Dwi Anggraeni yang menyatakan bahwa responden yang bergaya hidup tradisional di desa Mandiraja masih cukup tinggi hal ini dipengaruhi faktor geografis dimana desa Mandiraja termasuk desa terpencil sehingga mempengaruhi pemilihan jenis kontrasepsi seseorang, masyarakat pedesaan berasumsi KB implan dan IUD membahayakan sehingga mereka lebih banyak memilih KB suntik(9). Hal ini sesuai dengan pendapat Saifuddin yang menyatakan bahwa jenis KB suntikan banyak dipilih akseptor karena kerjanya yang efektif dan pemakaiannya yang praktis(5). Suntik DMPA aman, dapat dipakai oleh semua perempuan usia reproduksi, cocok untuk masa laktasi karena tidak mengganggu produksi ASI sedangkan KB implan memiliki kekurangan berupa nyeri kepala, peningkatan atau penurunan berat badan, mual, pening/ pusing, membutuhkan tindakan bedah minor untuk insersi dan pencabutan, tidak melindungi dari infeksi menular seksual, perubahan perasaan (mood) atau kegelisahan (nervousness), efektifitas menurun bila menggunakan obat tuberkulosis (rifampisin) atau obat epilepsi (fenotin dan barbiburat). Keuntungan suntik DMPA adalah pemakaiannya yang sederhana, menyenangkan, efektifitasnya tinggi.

Hasil penelitian menunjukkan bahwa akseptor suntik DMPA banyak mengalami gangguan menstruasi hal ini disebabkan karena suntik DMPA hanya mengandung hormon progesterone saja dimana kandungan progesterone tersebut dapat menyebabkan gangguan menstruasi sedangkan amenore yang tinggi disebabkan karena hormon progesterone menekan Lutein Hormon (LH) sehingga endometrium menjadi lebih dangkal dan mengalami kemunduran sehingga kelenjarnya menjadi tidak aktif. Hasil penelitian ini sesuai dengan pendapat Hartanto yang mengatakan bahwa kontrasepsi hormonal terutama yang mengandung progestin dapat mengubah menstruasi (1). M enurut Everett gangguan haid berupa amenore disebabkan karena progesteron dalam komponen DMPA menekan $\mathrm{LH}$ sehingga endometrium menjadi lebih 
dangkal dan atrofis dengan kelenjar-kelenjar yang tidak aktif (10).

Adapun perubahan siklus menstruasi pada KB implan sebanyak (42\%) mengalami menoragia. menoragia. Hasil penelitian tersebut bahwa gangguan menstruasi juga dialami oleh akseptor implan seperti pada KB DMPA, KB implan juga hanya mengandung hormon progesterone saja sehingga akseptor implan juga mengalami gangguan menstruasi. Menurut teori Hartantol mengatakan bahwa kontrasepsi hormonal terutama yang mengandung progestin dapat mengubah menstruasi. Hasil penelitian ini juga sesuai dengan teori yang dikemukakan oleh Baziad4 bahwa menorrhagia umumnya terjadi pada awal penggunaan alat kontrasepsi karena progesterone menyebabkan terbentuknya kembali pembuluh darah kapiler yang normal dengan sel-sel endotel yang intak dan sel-sel yang mengandung kadar glikoprotein yang cukup sehingga sel-sel endotel terlindung dari kerusakan, hal ini akan mempengaruhi mekanisme kerja hormon dan siklus haid yang normal, perdarahan akan lebih banyak. Berdasarkan tabel di atas diketahui bahwa hasil uji statistik diperoleh nilai $p=0,006$ yang lebih kecil dari $\alpha=0,05$; artinya HO ditolak dan $\mathrm{H} 1$ diterima atau ada perbedaan pengaruh perubahan siklus menstruasi antara akseptor yang menggunakan alat kontrasepsi kontrasepsi suntik Depo Medroksiprogesterone Asetat (DM PA) dengan Implan di Wilayah Kerja Puskesmas Karangan Kecamatan Karangan Kabupaten Trenggalek, akan tetapi perbedaan keduanya termasuk lemah. Hal ini ditunjukkan oleh hasil koefisien kontingensi 0,378. Perbedaan pengaruh gangguan menstruasi antara ibu yang menggunakan alat kontrasepsi implan dengan kontrasepsi suntik DMPA disebabkan karena adanya perbedaan kadar hormon yang terkandung di dalam KB suntik DMPA dan implan dimana pada implan kandungan hormonnya adalah $36 \mathrm{mg}$ levonorgestrel (Norplan), $68 \mathrm{mg}$ 3-Ketodesogestrel (Implanon), $75 \mathrm{mg}$ levonorgestrel (Jedena) sedangakan pada KB suntik DMPA efek progesteronenya kuat yaitu mengandung $150 \mathrm{mg}$ Depo Medroksiprogesterone Asetat sehingga gangguan menstruasi pada KB suntik DM PA lebih banyak dari pada KB implan selain itu pada KB implan pelepasan hormon terjadi secara bertahap yaitu melepaskan $80 \mu \mathrm{g}$ LNG setiap hari selama 6-18 bulan pertama, yang selanjutnya menurun sampai $30 \mu \mathrm{g}$ dan terus akan berlangsung sampai paling sedikit 5 tahun sehingga masih ada keseimbangan antara hormon progesterone dengan hormon estrogen alamiah hal ini yang menyebabkan gangguan menstruasi pada KB implan lebih sedikit dibandingkan KB suntik DM PA.

\section{KESIM PULAN}

Dari hasil penelitian ini dapat disimpulkan sebagai berikut

1. Sebesar $77,78 \%$ akseptor yang menggunakan KB suntik DM PA mengalami perubahan siklus menstruasi

2. Sebesar $57,78 \%$ akseptor yang menggunakan KB implant tidak mengalami perubahan siklus menstruasi

3. Ada perbedaan perubahan siklus menstruasi antara akseptor yang menggunakan alat kontrasepsi kontrasepsi suntik Depo Medroksi Progesterone Asetat (DMPA) dengan Implan di Wilayah Kerja Puskesmas Karangan Kecamatan Karangan Kabupaten Trenggalek.

\section{DAFTAR PUSTAKA}

1. Hartanto, H. Keluarga Berencana dan Kontrasepsi. Pustaka Sinar Harapan: Jakarta.

2. BKKBN, Keluarga Berencana, http://riau.bkkbn.go.id/old/ diunduh tanggal 6 Januari 2015.

3. Puji Lestari, Erna. 2013. Perbedaan Menstruasi Antara Akseptor KB yang Menggunakan Kontrasepsi IUD dengan Kontrasepsi Suntik 1 Bulan, Karya Tulis Ilmiah, Ponorogo: DIII Keperawatan Fakultas IImu Kesehatan

4. Hapsari, Reni. 2012. Hubungan Jenis Keluarga Berencana (KB) Suntik dengan Gangguan Menstruasi pada Akseptor KB Suntik di Bidan Praktek Swasta (BPS) Suhartini

5. Saifuddin. 2010.Buku Panduan Praktis Pelayanan Kontrasepsi, Jakarta: Rineka Cipta

6. Sinclair, C. 2009.Buku saku kebidanan. Diterjemahkan oleh: Renata, K. Jakarta: EGC. 
ISSN 1978-2071 (Print); ISSN 2580-5967 (Online) Jurnal IImiah Kedokteran Wijaya Kusuma 6 (1) : 8-13

7. Ekawati, Desi. 2010. Pengaruh KB Suntik DM PA terhadap Peningkatan Berat Badan di BPS Siti Syamsiyah Wonokarto Wonogiri, Karya Tulis IImiah, Surakarta: DIV Kebidanan Fakultas Kedokteran Universitas Sebelah Maret Surakarta

8. Notoatmodjo, S. 2005. Metodologi penelitian kesehatan. Jakarta: Rineka Cipta

9. Dwi Anggraeni, Mekar. 2009. Analisis Faktor-faktor yang Berpengaruh terhadap Perubahan Pola Menstruasi pada Akseptor KB Suntik Depo Medroksi Progesteron Asetat (DMPA) di Wilayah Kerja Puskesmas Sokaraja I Purwokerto, Jurnal Keperawatan Soedirman, Vol. 4 No. 2, Juli 2009.

10. Everett, S. 2007. Buku saku kontrasepsi dan kesehatan seksual reproduksi. Diterjemahkan oleh: Nike B.S. Jakarta: EGC 